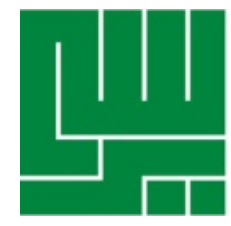

\title{
Motif Bekerja dan Pengelolaan Pendapatan pada Perempuan Menikah yang Bekerja di Dalam Rumah Tangga Dual Earner: Studi Awal pada Perempuan Berprofesi sebagai Dosen
}

\author{
Motives and Family Financial Arrangement \\ among Dual Earner Family: \\ Preliminary Studies among Female Lecturers \\ Entin Nurhayati ${ }^{1}$, Koentjoro Soeparno ${ }^{2}$, Wisjnu Martani ${ }^{3}$ \\ Mahasiswa Program Doktoral Fakultas Psikologi Universitas Gadjah Mada \\ ${ }^{1}$ Fakultas Psikologi Universitas YARSI \\ ${ }^{2,3}$ Fakultas Psikologi Universitas Gadjah Mada \\ Email: ${ }^{1}$ entin.nurhayati@yarsi.ac.id, ${ }^{2}$ koentjoro@ugm.ac.id, ${ }^{3}$ wisjnu_m@ugm.ac.id
}

KATA KUNCI Pengelolaan Keuangan, Motif Bekerja, Dual Earner.

KEYWORDS Financial Arrangement, Working Motive, Dual Earner.

ABSTRAK Perempuan menikah dan bekerja, dengan sejumlah penghasilan yang diperolehnya, sedikit banyak berpengaruh terhadap bagaimana perempuan tersebut memposisikan diri di dalam keluarga. Akses terhadap keputusan-keputusan keluarga, perasaan turut memberi andil pada setiap capaian keluarga, merupakan sedikit hal yang berubah ketika perempuan memiliki kontribusi ekonomi pada keluarga. Penelitian ini bertujuan untuk mendapatkan gambaran mengenai motif yang mendasari perempuan bekerja dan bagaimana sebuah keluarga dual earner mengelola penghasilan yang digunakan untuk keluarga. Dua tema yang menurut peneliti penting dalam memaknai penghasilan perempuan, sehingga memahaminya dapat bermanfaat dalam menjelaskan dinamika pengaruh penghasilan terhadap akses membuat keputusan atau power sharing di dalam keluarga. Studi ini dilakukan dengan metode fenomenologis, dan pengambilan data dilakukan dengan wawancara semi terstruktur. Wawancara dilakukan terhadap lima orang perempuan bekerja sebagai dosen tetap perguruan tinggi swasta di Jakarta. Responden telah menikah, berpendidikan tinggi (S2), mempunyai anak dan tinggal serumah dengan suami. Hasil wawancara dianalisis analisis tematik. Hasil analisis tematik menunjukkan empat macam motif bekerja yaitu (1) sudah menjadi cita-cita, (2) rasa aman, (3) aktualisasi diri, dan (4) hasil proses sosialisasi. Sedangkan untuk pengelolaan keuangan diperoleh tiga macam pola yaitu (1) terdapat pembagian pos-pos pengeluaran antara suami dan istri, (2) pendapatan suami sebagai sumber utama pembiayaan kebutuhan keluarga, dan (3) pendapatan istri sebagai sumber utama pembiayaan kebutuhan keluarga. Dari ketiga macam pengelolaan motif keuangan tersebut, tampak 
ABSTRACT Married and working mother, with the amount of income they earn, brought some change in her family. Access to family decisions, the feeling of contributing to each family's achievements, is kind of that changes when women have an economic contribution to the family. The aim of this research are to understand the motives of women get working, to understand how their family manage their income and how women's responses to that financial arrangement. Understanding of this theme is important for descript how women income take effect to decision making or power sharing in the family. This study was conductued using a phenomenological method, and data collection was carried out by semi-structured interviews. Interviews were conducted with five women working as permanent lecturers in privat universities in Jakarta. Respondents are married, highly educated (magister), have a children and live with their husbands. This research have three main question (1) what are the motives of responden to get a job event after married, (2) family financial arrangement, and (3) what are the response of respondent to their family financial arrangement. Data interview were analyzed with thematic analysis. The results show four kinds of working motives, namely (1) has become an ideal, (2) economic security, (3) self-actualization and (4) the results of socialization process. Whereas for financial management, there are three types of patterns. First, there is division of expenditure items between husband and wife, (2) husband's income as the main source of financing for family needs, and (3) wife's income as the main source of financing for family needs. Among those three kind of financial arrangement, it looks like responden does not use it as a bargaining position in family sharing power. It may be because of the working motive is more intrinsic, but it still need a further study for more accurate explanation.

\section{PENDAHULUAN}

Tingkat Partisipasi Angkatan Kerja (TPAK) perempuan di Indonesia mengalami peningkatan dari tahun ke tahun. Pada tahun 1990an hanya ada di kisaran 35\%, di tahun 2018 telah mencapai kurang lebih 55,44\% (Statistik, 2018). Karasu (2007) menyebutkan bahwa keterlibatan perempuan di dunia kerja berpengaruh besar terhadap kehidupan keluarga. Hal yang paling terlihat adalah pada struktur keluarga, berubah dari semula bersifat complementary - yaitu terdapat perbedaan peran antara suami dan istri, di mana keduanya saling melengkapi/complementer, yaitu suami sebagai pencari nafkah dan perempuan sebagai pengasuh anak serta penyelenggara rumah tangga -menjadi bersifat parallel, di mana peran-peran tersebut didistribusikan ulang antara suami dan istri (Ross dkk, dalam Brown \& Roberts, 2014; Smit, 2002).

Dua hal yang tampak mengubah wajah keluarga secara langsung adalah 
waktu dan penghasilan perempuan. Waktu yang dimiliki oleh perempuan tidak lagi hanya ditujukan untuk mengerjakan peran penyelenggara rumah tangga dan pengasuhan. Demikian pula, terdapat sejumlah pendapatan yang diperoleh perempuan yang secara langsung atau pun tidak langsung membuat perempuan turut berperan sebagai pencari nafkah. Riset mengenai dua hal ini telah banyak dilakukan di masyarakat Barat dengan memberikan gambaran bahwa hingga saat ini perubahan dalam hal pembagian pekerjaan di rumah tangga relatif kecil. Hingga saat ini, perempuan masih mengerjakan lebih banyak pekerjaan rumah tangga dan pengasuhan (Craig, 2007; Lennon \& Rosenfield, 1994; Wilkie, Ferre, \& Ratcliff, 1998).

Berkenaan dengan pendapatan perempuan, riset mengenai hal ini sering dikaitkan dengan isu power bargaining di dalam keluarga (Bianchi, Milkie, Sayer, \& Robinson, 2000); di mana semakin besar tingkat pendapatan semakin besar kemungkinan terjadi tarik menarik power dengan pasangan. Sebagaimana ditemukan oleh Treas dan Tai (2012) yang menyebutkan bahwa pada perempuan dengan pendapatan lebih tinggi dari pasangannya, mempunyai kecenderungan untuk mengambil sendiri keputusan berkaitan dengan berbagai urusan rumah tangganya. Seolah berkebalikan dengan temuan ini, bahwa perempuan dengan pendapatan lebih tinggi cenderung untuk melanggengkan peran-peran tradisionalnya dengan sikap diam terhadap pembagian kerja yang sudah ada (Mannino \& Deutsch, 2007). Hal ini menunjukkan terdapat variabel lain yang terlibat dalam bagaimana waktu dan pendapatan berpengaruh terhadap kehidupan keluarga. Salah satu yang terungkap adalah asertifitas. Mannino dan Deutsch (2007) menyebutkan pada perempuan dengan asertifitas tinggi, mengalami pengaturan pembagian kerja rumah tangga dan pengasuhan yang lebih seimbang dengan pasangan. Selain itu sikap terhadap peran gender, terutama pada lakilaki, berpengaruh dalam proses marital power ini (Kulik, 1999). Sedangkan pada penelitian di China menunjukkan terdapat hubungan yang negatif antara pembagian kerja rumah tangga yang bersifat rutin rutin dengan perbandingan relatif kontribusi pendapatan dan jumlah jam kerja (Kan \& He, 2018).

Selain berkaitan dengan asertifitas, sikap terhadap peran gender, bagaimana pendapatan berpengaruh terhadap pembagian kerja maupun power sharing di dalam rumah tangga, berkaitan pula dengan akses perempuan terhadap pendapatan tersebut. Meski perempuan memiliki penghasilan bahkan kadang lebih tinggi dari pasangannya, tidak serta merta membuat perempuan dan pasangannya berlaku equal dalam keputusan finansial keluarga (DemaMoreno, 2009). Bagaimana perempuan memiliki akses terhadap pendapatan tersebut, salah satunya dapat dilihat melalui bagaimana pengelolaan keuangan yang dibawa pulang untuk kepentingan keluarga. Berkaitan dengan hal tersebut, tulisan ini bermaksud melihat bagaimana pengelolaan keuangan keluarga dual earner dilakukan di Indonesia. Selain itu juga diungkap motif yang mendasari responden bekerja. Penelitian ini merupakan penelitian awal dengan enam responden sebagai sebuah awalan penelitian untuk melihat pola pengelolaan keuangan keluarga dual earner di Indonesia, sekaligus berupaya melihat motif perempuan bekerja.

\section{METODE PENELITIAN \\ Pendekatan Penelitian}

Studi ini menggunakan pendekatan kualitatif, dengan desain fenomenologi, yaitu berusaha memahami sebuah fenomena dari sudut pandang pelaku.

\section{Partisipan}

Pemilihan responden dalam penelitian ini adalah dengan metode sampling purposive, di mana sejak awal peneliti telah menentukan karakteristik 
tertentu dari subjek. Responden dalam penelitian ini terdiri dari enam dosen dari sebuah perguruan tinggi swasta di Jakarta. Pemilihan ini semata dalam rangka membatasi kemajemukan data yang mungkin muncul dari latar belakang profesi. Adapun ciri-ciri responden penelitian ini adalah:

Tabel 1

Karakteristik Partisipan

\begin{tabular}{|c|c|c|c|c|c|c|}
\hline $\begin{array}{c}\text { Respon } \\
\text { den }\end{array}$ & $\begin{array}{c}\text { Responde } \\
\text { n RT }\end{array}$ & $\begin{array}{c}\text { Responde } \\
\text { n SE }\end{array}$ & $\begin{array}{l}\text { Responde } \\
\text { n TD }\end{array}$ & $\begin{array}{c}\text { Responde } \\
\text { n WN }\end{array}$ & $\begin{array}{c}\text { Responde } \\
\text { n RD }\end{array}$ & $\begin{array}{c}\text { Responde } \\
\text { n } \\
\text { SA }\end{array}$ \\
\hline Usia & 30 thn & 32 thn & 46 thn & 42 thn & 33 thn & 43 \\
\hline $\begin{array}{l}\text { Pengatu } \\
\text { ran } \\
\text { tempat } \\
\text { tinggal }\end{array}$ & $\begin{array}{l}\text { Dengan } \\
\text { suami dan } \\
\text { anak }\end{array}$ & $\begin{array}{l}\text { Dengan } \\
\text { ibu } \\
\text { kandung, } \\
\text { suami dan } \\
\text { anak }\end{array}$ & $\begin{array}{l}\text { Dengan } \\
\text { suami dan } \\
\text { anak }\end{array}$ & $\begin{array}{l}\text { Dengan } \\
\text { suami dan } \\
\text { anak }\end{array}$ & $\begin{array}{l}\text { Dengan } \\
\text { suami, } \\
\text { anak, adik } \\
\text { dan orang } \\
\text { tua }\end{array}$ & $\begin{array}{l}\text { Dengan } \\
\text { suami dan } \\
\text { anak }\end{array}$ \\
\hline $\begin{array}{l}\text { Tanggu } \\
\text { ngan }\end{array}$ & Anak & $\begin{array}{l}\text { Ibu dan } \\
\text { anak }\end{array}$ & Anak & Anak & Anak & Anak \\
\hline $\begin{array}{l}\text { Jumlah } \\
\text { anak }\end{array}$ & $\begin{array}{l}1 \text { anak } \\
\text { kandung }\end{array}$ & $\begin{array}{l}2 \text { anak } \\
\text { kandung }\end{array}$ & $\begin{array}{l}2 \text { anak } \\
\text { kandung }\end{array}$ & $\begin{array}{l}3 \text { anak } \\
\text { kandung }\end{array}$ & $\begin{array}{l}2 \text { anak } \\
\text { kandung } \\
1 \text { anak } \\
\text { angkat }\end{array}$ & $\begin{array}{l}4 \text { anak } \\
\text { kandung }\end{array}$ \\
\hline $\begin{array}{l}\text { Usia } \\
\text { anak }\end{array}$ & 2 thn & $\begin{array}{l}3 \text { thn } \\
1 \text { thn }\end{array}$ & $\begin{array}{l}15 \text { thn } \\
12 \text { thn }\end{array}$ & $\begin{array}{l}15 \text { thn } \\
11 \text { thn } \\
9 \text { thn }\end{array}$ & $\begin{array}{l}10 \text { thn } \\
2 \text { thn } \\
10 \text { thn }\end{array}$ & $\begin{array}{l}17 \text { thn } \\
15 \text { thn } \\
13 \text { thn } \\
6 \text { thn }\end{array}$ \\
\hline $\begin{array}{l}\text { Masa } \\
\text { kerja }\end{array}$ & 3 tahun & 4,5 thn & 12 thn & 10 thn & 4 thn & 20 thn \\
\hline $\begin{array}{l}\text { Jabatan } \\
\text { akadem } \\
\mathrm{ik}\end{array}$ & $\begin{array}{l}\text { Asisten } \\
\text { ahli }\end{array}$ & $\begin{array}{l}\text { Asisten } \\
\text { ahli }\end{array}$ & $\begin{array}{l}\text { Asisen } \\
\text { ahli }\end{array}$ & $\begin{array}{l}\text { Asisten } \\
\text { ahli }\end{array}$ & $\begin{array}{l}\text { Asisten } \\
\text { ahli }\end{array}$ & Lektor \\
\hline $\begin{array}{l}\text { Jam } \\
\text { kerja }\end{array}$ & $\pm 40 \mathrm{jam}$ & $\pm 40 \mathrm{jam}$ & $45-50$ jam & \pm 40 jam & \pm 40 jam & $\begin{array}{l}20-30 \\
\text { jam }\end{array}$ \\
\hline
\end{tabular}

\section{Instrumen Penelitian}

Pengumpulan data dilakukan dengan wawancara tatap muka, semi terstruktur, di mana terdapat tiga pertanyaan utama, disertai dengan pertanyaanpertanyaan yang menggali lebih lanjut dari jawaban-jawaban responden. Wawancara semi terstruktur ini merupakan cara untuk mengatasi kelemahan dari wawancara terstruktur di mana terdapat dinamika di dalam sebuah proses wawancara. Sebagaimana Fontana dan Frey (2009) menyebutkan bahwa seorang peneliti harus lebih menyadari kemajemukan responden dan harus cukup fleksibel dalam membuat penilaian-penilaian yang pantas untuk mengantisipasi perekembangan yang terjadi selama proses wawancara. Sebagai upaya menjaga validitas data, dilakukan triangulasi peneliti/rater. Dalam hal ini data yang telah dilakukan koding, disajikan kepada tiga orang rater untuk dinilai kesesuaian antara koding dengan data mentahnya. Semakin banyak rater yang memberikan penilaian yang sama, maka hasil koding dapat diterima. Dalam hal ini dua dari tiga rater menyepakati koding yang dilakukan peneliti. Sedangkan satu rater memberikan beberapa catatan pada beberapa koding yang dilakukan peneliti. 
Pertanyaan yang diajukan kepada responden terdiri dari tiga pertanyaan utama yang diikuti dengan pertanyaan-pertanyaan yang bersifat menggali lebih jauh dari jawaban-jawaban responden. Pertanyaanpertanyaan utama tersebut adalah (1) apa cita-cita dan alasan memilih hal itu?, (2) bagaimana keuangan keluarga Anda dikelola?, (3) bagaimana tanggapan Anda berkenaan dengan pengaturan keuangan tersebut? Pertanyaan lebih lanjut dibuat sesuai dengan perkembangan jawaban responden.

\section{Prosedur Penelitian}

Dalam mendapatkan responden, prosedur yang dilakukan adalah (1) membuat janji bertemu orang-orang sesuai dengan kriteria, (2) melakukan rapport, (3) menyampaikan maksud dan tujuan studi, (4) meminta kesediaan untuk berpartisipasi, (5) membuat janji pertemuan dan melakukan wawancara. Rapport dilakukan dengan memulai percakapan seputar pekerjaan dan bagaimana responden mengenal tempat kerja saat ini. Ketika percakapan sudah lancar dan rileks, peneliti menyampaikan maksud dan tujuan wawancara. Setelah responden menyatakan kesediaannya diwawancara, maka alat rekam dinyalakan dan mulai diajukan pertanyaan-pertanyaan penelitian. Setiap wawancara berlangsung antara satu hingga dua jam dan direkam dan voice recorder.

\section{Teknik Analisis Data}

Data yang diperoleh berupa rekaman - dibantu oleh verbatimer diubah dari data audio ke data tulisan. Untuk menjaga akurasi verbatim, peneliti mendengar ulang rekaman sambil membaca hasil verbatim, sambil melakukan koreksi jika terdapat hal yang terlewat atau kurang tepat. Dari data mentah tersebut, setelah membaca ulang verbatim yang telah dikoreksi, peneliti memberikan catatan tema-tema pada tiap ungkapan yang dinilai bermakna, melihat keterkaitan antar tema, kemudian beranjak pada verbatim partisipan berikutnya. Setelah semua verbatim dibuat bagan, dilihat adakah kesamaan keterkaitan antara tema dari ke enam partisipan tersebut. Analisa data menggunakan analisis tematik dari Braun dan Clarke (2006). Analisis ini melalui enam fase yaitu (1) membiasakan diri dengan data, yaitu dimulai dengan melakukan transkrip daya, membaca dan membaca ulang data dan membuat catatancatatan awal untuk memulai koding; (2) membuat kode awal, yaitu dengan memberikan kode pada gambarangambaran yang menarik pada data secara sistematis pada keseluruhan data, mengumpulkan data-data yang relevan pada setiap kode; (3) mencari tema, yaitu dengan mengumpulkan kode-kode pada tema-tema potensial, mengumpulkan semua data yang relevan pada tiap tema yang potensial; (4) mereview tema-tema yaitu dengan melakukan pemeriksaan apakah tema-tema tersebut bekaitan dengan kode-kode yang telah diekstrak dan data secara keseluruhan, selanjutnya membuat tema secara keseluruhan; (5) mendefinisikan dan memberi nama tema, analisis yang dijalankan untuk menghaluskan secara lebih spesifik setiap tema, dan cerita keseluruhan dari analisis, membuat definisi yang jelas dari tema dan menamai setiap tema; (6) membuat laporan.

\section{ANALISIS DAN HASIL}

Dari hasil wawancara diperoleh gambaran sebagai berikut:

\section{Pertanyaan 1: Motif Bekerja dan Pilihan Pekerjaan}

Terdapat berbagai macam alasan bagi responden ini untuk tetap menyandang status bekerja setelah menikah. Satu kesamaan diantara mereka adalah niat untuk bekerja tersebut sudah ada sejak masih menempuh pendidikan tinggi. Dari ungkapan-ungkapan responden, peneliti melihat bahwa motivasi tersebut lebih diwarnai oleh motif intrinsik, sebuah kebutuhan yang muncul dari dalam diri 
sendiri. Meskipun ada pula motif yang merupakan hasil sosialisasi dari lingkungan dan orang tuanya, tetapi hal itu sudah menjadi bagian dari dalam diri responden.

Status bekerja merupakan hal yang sudah diniatkan dari awal sebelum menikah. Sejak menempuh pendidikan tinggi, niat untuk bekerja setelah lulus sudah muncul. Pada mulanya tidak terbayang oleh responden, akan bekerja sebagai apa, menekuni bidang apa dan seterusnya. Bidang kerja, profesi yang digeluti merupakan sesuatu yang dipilih berdasarkan kesempatan dan kecocokan yang muncul bersamaan dengan kelulusan pendidikan tinggi yang ditempuhnya. Seperti halnya Ibu WN yang menyebutkan sebagai berikut:

"Yang kebayang ya lulus, kerja gitu ya ya kayak...kayak kerja kantor gitu aja. Jadi nggak spesifik jadi dosen itu" (S1-WN-9 s.d 10).

Sebelum menekuni profesi dosen, beberapa responden sempat menjalani pekerjaan sebagai freelancer. Dengan memanfaatkan jaringan yang ada, job-job yang diperoleh berupa assessment, recruitment, training dan juga konsultasi. Setelah itu mendapat kesempatan untuk bergabung menjadi dosen tetap di sebuah PTS di Jakarta. Seperti halnya Ibu TD, yang kemudian memilih untuk mengambil kesempatan ini, di mana lebih diniatkan untuk mendapatkan rasa aman secara finansial, berkenaan dengan kondisi pekerjaan pasangan. Secara lebih spesifik Ibu TD menyebutkan niatan bekerja secara lebih mapan ini adalah untuk mendapatkan rasa aman secara finansial, karena suami saat itu memutuskan untuk berwiraswasta. Di mana sebagai sebuah usaha rintisan, belum mampu memberikan penghasilan yang rutin dan mencukupi.

"Pertama-tama kalo balik lagi kenapa memutuskan untuk bekerja (tetap-catatan peneliti) mencukupi, fokusnya mencukupi. Karena sebelumnya suami kan ke wirausaha, penghasilan tidak tetap tapi sekarang udah jadi karyawan, karyawan kontrak sih sebenarnya tapi itu penghasilannya jauh lebih baik (S2-TD-10 s.d. 12)".

Sebagai perempuan-perempuan berpendidikan tinggi, kesadaran untuk aktualisasi diri menjadi sebuah kebutuhan. Pada responden juga ditemukan adanya niatan bekerja yang dilandasi keinginan untuk aktualisasi diri. Lebih khusus yaitu menyalurkan potensi dirinya. Sebagaimana yang diungkapkan oleh Ibu RT berikut:

"Dan selain, sebelum menikah udah mulai bekerja duluan juga, setelah menikah pun, bekerja itu bukan mencari nafkah, tidak pernah terpikirkan 'oh ini uang, ini untuk memenuhi kehidupan kami' tidak pernah, karena dari awal pernikahan sudah ditekankan oleh suamiku bahwa nafkah itu dari saya bukan dari kamu, kamu hanya untuk aktualisasi diri aja" (S3-RT-.31 s.d. 34).

Pada ungkapan Ibu RT, dengan mengkontraskan dengan sejumlah uang yang diperoleh dari pekerjaan tersebut, Ibu RT lebih merasa bekerja sebagai sebuah penyaluran potensi dan aktualisasi diri. Dengan pendidikan tinggi yang dimiliki, Ibu RT merasa memiliki skill dan ilmu yang harus dimanfaatkan buat masyarakat. Di mana kemanfaatan tersebut penting bagi perasaan diri telah beraktualisasi.

Sedangkan motif selanjutnya, lebih didasarkan pada proses sosialisasi yang telah dilalui. Sebagaimana yang diungkapkan oleh RT dan RD, sekalipun pengalamannya berbeda. Pada responden RT selain karena sudah terbiasa melihat kedua orangtuanya bekerja, juga terdapat keyakinan di lingkungan sosialnya, bahwa menjadi ibu rumah tangga semata adalah memiliki nilai sosial yang rendah.

"Karena kan ibuku orang bekerja, lebih... kalau orang *** (nama 
daerah - peneliti) itu bekerja itu lebih baik dari pada di rumah doang, dibandingkan jadi ibu rumah tangga. Jadi ibu rumah tangga tuh nista, ya gitu lah" (S3-RT-124 s.d 125).

Pada responden RD, lebih didasarkan pada pengalaman yang ia alami dan lihat dari sosok ibunya. Ibu RD adalah ibu rumah tangga yang mendapat perlakuan kurang menyenangkan dari ayah berkenaan dengan kecukupan nafkah.

“...pemisalan belanja bayam dengan harga seribu, maka ayah akan memberikan uang lima ratus rupiah kepada ibu, padahal di kacamataku untuk seorang dokter yang tergolong sukses, bukan hal yang sulit untuk memberikan seribu rupiah, bahkan sampai dengan lima ribu pun adalah hal yang mudah bagi ayah..."(S4-RD-12 s/d 16).

Pada perempuan-perempuan responden ini, meski memilih tetap bekerja dan mendapatkan penghasilan sendiri, dalam hal memilih jenis pekerjaan, lebih didasarkan pada pertimbangan bagaimana ia dapat menjalankan tanggungjawab perempuan. Responden pada tulisan ini meyakini bahwa perempuan bertanggungjawab untuk lebih banyak mendampingi anak-anak dan juga tanggungjawab domestik lainnya di dalam keluarga. Sebagaimana disampaikan oleh Ibu TD dan RT berikut:

"Jadi aku bisa bilang dia workaholic lah. Maksudnya kalo ada ee...pemikiran dia akan mikirin terus dan terus laksanain sampe itu tuntas sehingga aku tau dia nggak akan bisa fokus ke keluarga sehingga aku..., saya mikir saya harus in charge di keluarga, gitu... Jadi akhirnya itu jadi pertimbangan utama sih untuk memilih pekerjaan apa gitu karena aku pikir aku juga gak mau gila-gilaan kerja karena suami juga udah terbukti sekarang yang pasti adalah anak harus ada pendamping orangtua gitu loh" (S2TD-5 s.d 10).

"Tapi enggak deh saya pikir-pikir kalau kerjaannya kayak gitu nanti kalau saya berumah tangga gimana" (S6-RT-48 s/d 49).

Pada Ibu TD kesadaran memilih pekerjaan yang dianggap ramah terhadap peran sebagai ibu dan istri, diputuskan setelah melihat bagaimana suami dalam hal menekuni pekerjaan. Artinya Ibu TD berusaha menyelaraskan pilihan pekerjaannya, dengan suami, sehingga peran-peran parenting dan urusan rumah tangga tetap dapat terjaga. Sedangkan pada Ibu RT, pilihan pekerjaan yang dianggap ramah terhadap peran domestik perempuan, sudah dilakukan sebelum menikah. Artinya sejak mula, Ibu RT sudah meyakini dan menyiapkan diri untuk menjalankan peran domestik di dalam berkeluarga.

Dari gambaran di atas, dapat dilihat bahwa terdapat empat macam motif untuk bekerja, yaitu (1) sudah menjadi cita-cita, (2) rasa aman, (3) aktualisasi diri, dan (4) hasil proses sosialisasi. Sedangkan pilihan pekerjaan lebih didasarkan pada pertimbangan pembagian peran tradisional di mana perempuan memegang peran utama pada domain domestik dan pengasuhan sehingga dipilihlah pekerjaan yang dirasa masih memberi peluang besar untuk tetap dapat menjalankan peran tradisionalnya.

\section{Pertanyaan 2: Pengelolaan Keuangan dalam Keluarga}

Dari ke enam responden, terdapat tiga macam pengelolaan keuangan keluarga. Pengelompokkan ini didasarkan pada bagaimana pendapatan keluarga tersebut berasal dan siapa yang mengelolanya. Kategori tersebut adalah (1) antara suami dan istri berbagi pos pengeluaran, di mana suami memegang pos pengeluaran pokok, biasanya pengeluaran yang bersifat besar dan jangka panjang, (2) pendapatan suami sebagai sumber 
pendanaan rumah tangga, istri mengelola dana tersebut untuk keperluan keluarga, dan (3) pendapatan istri menjadi sumber dana utama untuk keperluan rumah tangga.

Termasuk dalam kategori pertama adalah responden yang melakukan pembagian pos-pos pengeluaran, yaitu pada Ibu WN dan Ibu RD. Pembagian pos-pos didasarkan pada kategori pengeluaran pokok dan non pokok. Termasuk dalam kategori pokok adalah pengeluaran yang relatif besar seperti cicilan rumah, kendaraan, biaya sekolah anak dan belanja bulanan. Pengeluaran pokok ini menjadi tanggung jawab suami, sedangkan pengeluaran non pokok menjadi tanggung jawab istri. Termasuk dalam pengeluaran non pokok adalah tagihan listrik, air pam, belanja sayur mayor dan lauk harian. Sebagaimana ungkapan Ibu WN dan Ibu RD berikut:

"Kalau sekarang sih..., ya kebutuhanku sendiri, terus beberapa pos, kayak listrik...eh listrik bukan, telephone, tagihan handphone, terus tagihan PDAM, itu pakai uangku..." (V1-WN-35 s/d 36)

"Jadi misalnya suami itu hal-hal yang kita anggap sebagai pokok, misalnya bayar cicilan rumah..., terus...e...bayar sekolah anak... eee yang kita anggap itu adalah ya pokoknya memang itu harus kepala keluarga yang membayarlah begitu" (V1-RD-81 s/d 85).

Pada model pengelolaan ini, masing-masing memegang pendapatannya sendiri-sendiri. Jika terdapat rencana pengeluaran yang besar, maka hal tersebut akan dibicarakan dengan pasangan dan dibiayai berdua, besarannya tergantung dari kesediaan dana dan kesanggupan masingmasing. Pengeluaran ini misalnya renovasi rumah, biaya pendaftaran sekolah anak.

Kategori kedua adalah suami memberikan sejumlah uang kepada istri untuk memenuhi kebutuhan rumah tangga.
Termasuk dalam model ini adalah Ibu TD, RT, dan SA. Dari ketiga responden tersebut, terdapat variasi. Pada Ibu SA dan Ibu RT, perkiraan pengeluaran telah dibuat di akhir bulan sebelumnya, dan suami akan berusaha memberikan sesuai dengan kebutuhan tersebut. Pendapatan istri dapat digunakan untuk keperluan istri atau pun untuk anak-anak, yaitu kebutuhan yang sifatnya bukan kebutuhan pokok. Kebutuhan istri tersebut misalnya untuk transportasi, biaya sekolah pada waktu sekolah, untuk orang tua, membantu kerabat dan lainnya. Sedangkan pada Ibu TD, suami memberikan sejumlah uang sesuai dengan pendapatannya. Ketika pendapatannya besar maka diberikan dalam jumlah besar dan ketika kecil, diberikan dalam jumlah kecil. Dengan demikian, dengan keadaan seperti ini, pendapatan Ibu TD, terpakai pula untuk rumah tangga ketika suami mengalami penurunan pendapatan. Sebagaimana ungkapan Ibu TD berikut:

“...sekarang lebih mudah karena dia punya penghasilan tetap jadi paling enggak aku bisa ngeliat dia dapet segini terus kita bicarain aku pengeluaran segini segini untuk anak-anak, untuk keluarga segini segini kemudian dia memberikan gitu loh segini gitu..." (V1-TD-73 s/d 75).

Pada Ibu RT dan SA, suami berusaha untuk memenuhi kebutuhan rumah tangga, termasuk ketika ternyata di tengah bulan terdapat pengeluaran di luar yang dianggarkan. Hal ini tak lepas dari keyakinan agama dari pasangan ini, yaitu bahwa nafkah keluarga adalah tanggungjawab suami. Sebagaimana yang diungkapkan Ibu SA, ketika Ibu SA berniat menutupi kekurangan tersebut sambil menyebutkan bahwa itu adalah bernilai sodaqoh, maka suami melarang hal tersebut dan berusaha memenuhi kebutuhan tersebut. Dengan kata lain, secara aktif, Ibu 
SA menjaga agar peran memenuhi kebutuhan keluarga tetap ada pada suami.

"He em mbak. Dia kan tahu hukumnya seperti itu. Itu tanggung jawabnya dia. Kalau pun misalnya istri tu sampe menambahi atau apa, itu sedekahnya istri. Kalo di agama kan seperti itu..." (V1-SA-131 s/d 133).

Makanya kadang kalo..., "Ibu, kok jadi menipis ya?" "Ckk, Ibu dong nyumbang dong." "Ya udah, mau aku sedekahin deh", terus, "Ah ya udah ya udah nggak usah simpen aja" (V1-SA-135 s/d 136).

Kategori ketiga adalah pendapatan istri menjadi utama untuk memenuhi kebutuhan keluarga. Termasuk dalam kategori ini adalah Ibu SE. Meski demikian, menurut Ibu SE hal ini bersifat sementara, yaitu pada saat suaminya sedang merintis usaha sendiri. Pada waktu awal-awal menikah, suami memiliki pekerjaan tetap dan pengelolaan keuangannya sebagaimana pada model pertama di atas. Satu tahun belakangan, suami memutuskan berwirausaha dan hingga saat ini belum mendatangkan pendapatan sebagaimana diharapkan, sehingga pendapatan RT-lah yang dijadikan sumber utama memenuhi kebutuhan keluarga.

"Apalagi tahun ini kondisi suami masih labil keuangannya. Jadi sebagian besar masih dari aku" (V1RT-160 s/d 161).

\section{Pertanyaan 3: Tanggapan Responden terhadap Pengelolaan Keuangan Keluarga}

Di atas disebutkan terdapat tiga pola pengelolaan keuangan keluarga. Bagaimana perempuan-perempuan ini menanggapi pengelolaan tersebut, berikut adalah uraiannya.

Pada kategori pertama, yaitu terjadi pembagian pos antara suami dan istri, baik Ibu WN maupun Ibu RD merasa hal tersebut cukup adil. Apalagi suami tetap menjadi sumber utama bagi pendanaan keperluan keluarga, dalam hal ini Ibu WN maupun Ibu RD merasa keterlibatannya dalam membiayai keluarga adalah sebagai pelengkap dan meningkatkan standar konsumsi keluarga. Meski diakui jika responden berhenti bekerja, banyak pos-pos pengeluaran yang harus disesuaikan, seperti standar makan, rekreasi dan yang lainnya, termasuk untuk pengeluaran pribadi.

"Jadi misalnya suami itu hal-hal yang kita anggap sebagai pokok, misalnya bayar cicilan rumah..., terus...e...bayar sekolah anak... eee yang kita anggap itu adalah ya pokoknya memang itu harus kepala keluarga yang membayarlah begitu" (V1-RD-82 s/d 84).

"Yak, it's fair enough. Tidak merasa gini, akhirnya kan dia tidak membelikan... tidak secara...begini, kalau secara pembagian kok tidak suamiku yang belanja-belanja sayur dan segala macam. Kan orang mungkin kalau mendefinisikan nafkah seperti itu. .... Tapi e...jadinya sudut pandangnya itu...definisi nafkah itu...misalnya kayak dia bayarin cicilan, bayarin sekolah, itu juga bagian dari nafkah gitu kan" (V1-RD-203 s/d 209).

Pembagian yang demikian juga memberikan rasa percaya diri pada responden untuk terlibat dalam mengatur tujuan dan target-target keluarga, karena merasa memiliki kemampuan untuk turut mewujudkannya. Di sini tampak bahwa meskipun status responden bekerja dan memiliki pendapatan, keyakinan bahwa tanggungjawab nafkah ada pada suami masih dipercaya sebagai norma yang berlaku dalam keluarga. Sebagaimana ungkapan Ibu RD dan Ibu WN berikut:

"Signifikan... karena kalau standar hidup kita nggak mahal. Jadi kalau cuma untuk memenuhi kebutuhan 
hidup itu sendiri, it s ok. Nah kalau aku sendiri bekerja, dengan gajiku ini lebih untuk gaya hidupku saja. ... Yang itu aku pengin jajan-jajan gitu, pengin beli-beli baju... jalanjalan, makan... Kan misalnya sama temen-temen nih, yuk kita main ke Artha Gadhing misalnya, ya yang gitu-gitu aja. Atau bahkan untuk investasiku sendiri, misalnya beli LM" (V1-RD-124 s/d 130).

"Kalau setelah (responden pindah kerja-peneliti) di * (institusi saat ini tempat bekerja - peneliti), iya (signifikan-peneliti).

E...signifikan itu ya berarti kalau dibandingkan dengan kerja kantoran yang lain tidak jauh beda gitu ya... Kemudian ya secara...apa namanya... di dalam keluarga sendiri aku bisa membantu... apa namanya... mencukupi beberapa pos gitu.... Terutama untuk kebutuhanku sendiri, itu lebih dari cukup" (V1-WN-21 s/d 28).

Pada kategori kedua, yaitu suami sebagai sumber pendanaan kebutuhan keluarga. Terdapat tiga responden yang dapat dikategorikan pada model ini, yaitu Ibu RT, SA dan TD. Pada Ibu RT dan Ibu SA, sebagaimana dikemukakan di atas lebih banyak didasari pada kesadaran pasangan bahwa nafkah keluarga sepenuhnya tanggungjawab suami, pun ketika ternyata terdapat kebutuhan-kebutuhan mendadak. Sebagaimana ungkapan Ibu TD dan RT berikut:

"...karena dia sendiri berpendapat bahwa dia sebagai kepala keluarga wajib memenuhi nafkah" (V1-TD$75 \mathrm{~s} / \mathrm{d} 76)$.

"Karena dia sendiri merasa suami adalah orang yang bertanggung jawab sekali. Saya menyukai visi dia yang kayak gitu. Berarti dia bertanggung jawab, gitu" (V1-RT$80 \mathrm{~s} / \mathrm{d} 81)$.
Ibu RT dan Ibu SA merasa memang sudah seharusnyalah demikian. Sehingga mereka dapat melakukan saving dan membuat perencanaan jangka panjang seperti merenovasi rumah dan melanjutkan studi.

Sedikit berbeda dengan Ibu TD di mana pengaturan keuangan yang demikian lebih didasarkan pada kebiasaan yang diperoleh oleh suami dari keluarga asal. Pada keluarga asal suami Ibu TD, ayah memegang semua pendapatan dan ibunya adalah ibu rumah tangga yang mendapat sejumlah dana dari ayah untuk membiayai keluarga. Demikian pula yang diterapkan suami Ibu TD. Berbeda dengan keluarga asal Ibu TD.Pada keluarga asalnya, ibulah yang memegang semua pendapatan baik dari ayah maupun ibu, dan ayah mendapat uang saku dari Ibu. Di awal-awal berumah tangga, Ibu merasa sering kerepotan mengatur keuangan keluarga apalagi ketika pendapatan suaminya menurun, yang berimbas pada berkurangnya belanja keluarga.

Pada kategori ketiga, yaitu pendapatan istri sebagai sumber keuangan keluarga, terjadi pada Ibu SE. Sebagaimana dikemukakan di atas, kondisi ini direncanakan bersifat sementara, hingga usaha yang dirintis oleh suami dapat memberikan penghasilan sebagaimana mestinya. Ibu SE tidak merasa keberatan dengan hal ini, karena meyakini hanya bersifat sementara dan merupakan wujud dukungan terhadap suami.

Dari ketiga bentuk pengelolaan keuangan rumah tangga, dilihat dari sumber pendapatan utama untuk keperluan keluarga, terdapat satu benang merah yang sama, yaitu pada ketiganya terdapat keyakinan bahwa nafkah merupakan tanggungjawab suami. Pendapatan istri bersifat melengkapi atau pun jika menjadi sumber utama maka sifatnya hanyalah sementara hingga suami kembali mampu mencukupi keperluan keluarga.

Selain itu dalam menempatkan suami sebagai pencari nafkah utama, tidak 
terlepas dari upaya istri untuk menjaga kebanggan pasangan sebagai laki-laki yang dapat memenuhi kebutuhan keluarga. Sebagaimana ungkapan-ungkapan berikut:

"Suamiku selalu menekankan, kalau soal uang dia yang utama gitu. Dia yang utama, jadi...apa namanya...dia selalu berusaha kalau yang...kayak...kita pergi makan, belanja, belanja bulanan, dia yang bayar. Jadi e....kalau uangku dipakai kalau dia nggak ada. Ya itu salah satu usaha kita juga untuk...bahwa pencari nafkah utama tetep suami "(V1-WN-169 s/d 172).

"Walaupun itu ada sisi pridenya dia, harga dirinya dia dalam keinginan untuk diakui oleh isterinya. Tapi emang seperti itu, kita sebagai isteri gak boleh kurang ajar, kita gak boleh take over semuanya sehingga kita merasa bahwa kita bisa kok hidup sendiri tanpa lo. Kalau sekarang sih aku udah mulai..., kalau kemarin beli sesuatu ya udah beli aja, kalau sekarang aku udah mulai bertanya boleh gak. Mulai bertanya boleh gak beli, atau butuh gak ya beli ini, nanti biasanya dia yang akan belikan' (V1-RT-81 s/d 86)

Dari tiga pola pengelolaan keuangan keluarga sebagaimana dikemukakan di atas, secara umum responden dapat menerima dan merasa nyaman dengan pengelolaan keuangan tersebut. Pada kelompok pertama, kenyamanan lebih bersumber pada perasaan adil dan juga ada perasaan turut andil dalam memenuhi kebutuhan dan mencapai tujuan keluarga. Pada kelompok kedua, kenyamanan lebih bersumber pada keyakinan bahwa tanggungjawab peran breadwinner secara norma adalah ada pada suami dan hal tersebut sejalan dengan pola pengelolaan keuangan keluarga. Sedangkan pada kelompok ketiga, di mana sumber keuangan utama adalah istri, kenyamanan lebih bersumber pada keyakinan bahwa pasangannya tetap terus berusaha untuk memenuhi tanggungjawabnya sebagai breadwinner, sehingga suatu waktu peran utama perempuan dalam memenuhi kebutuhan keluarga ini berubah.

Selain itu terdapat hal-hal yang dirasa berpotensi menimbulkan perasaan tidak nyaman pada pihak istri. Hal tersebut diantaranya adalah berkaitan dengan perasaan adil terhadap peran dan berkaitan dengan hobi pasangan. Berkaitan dengan perasaan adil, sebagaimana dikemukakan Ibu TD berikut:

"Pada awal-awal ada saat-saat pada saat itu sih kondisi suami lagi sulit sih kondisinya pada saat itu aku jadi wadek jadi penghasilan juga gede kan. Ada saat-saat dimana aku ngerasa kesel gitu "kok jadi aku sih yang ini..ahh..uangku lagi uangku lagi" ya ada kayak gitu ya tapi kemudian eee...dengan komunikasi apa lagi aku juga liat kemampuan finansial makin baik dan bisnis makin berhasil dan itu yang kemudian bisa kita komunikasikan sih jadinya gitu loh". (V1-TD-92 s/d 97).

Berkaitan dengan hobi, terkadang pihak istri merasa belanja yang dikeluarkan pasangan untuk hobi adalah berlebihan. Sebagaimana ungkapan Ibu WN berikut ini:

"Ya itu untuk beli pakan kucing itu...hahahaha...menurutku itu hal yang sia-sia tidak ada gunanya... itu...terus... E...awalnya berpengaruh, karena cukup besar. Karena untuk beli pasir aja satu setengah (juta - peneliti)". (V1WN-98-99; V1-WN-101-102).

\section{DISKUSI \\ Motif Bekerja dan Pilihan Pekerjaan}

Dari temuan di atas, dapat dilihat bahwa dalam hal menentukan bekerja atau tidak, sudah direncanakan oleh responden 
sejak masih menjalani masa kuliah. Dari empat alasan bekerja - yaitu (1) sudah menjadi cita-cita, (2) rasa aman, (3) aktualisasi diri, dan (4) hasil proses sosialisasi - motif tersebut terbentuk sebelum menikah dan/atau dikuatkan setelah pernikahan. Motif yang terbentuk sebelum menikah adalah alasan pertama yaitu sudah menjadi cita-cita dan ketiga yaitu aktualisasi diri. Cita-cita tersebut lebih didasari oleh tingkat pendidikan yang mengkondisikan responden untuk beraktifitas di luar rumah dan memanfaatkan keilmuan yang telah diperoleh.

Selain itu motif yang terbentuk sebelum menikah adalah merupakan hasil proses sosialisasi yang dijalani. Proses sosialisasi ini utamanya berasal dari pengasuhan dan status orangtua asal di mana ibu dari responden adalah berstatus bekerja. Dalam hal pengasuhan orang tua menanamkan harapan-harapan dan nilainilai mengenai perempuan bekerja. Seperti yang dialami oleh salah satu responden yang menyebutkan bahwa keluarganya mengajarkan bahwa lingkungan lebih menghargai perempuan ketika perempuan memiliki pekerjaan dan sumber penghasilan sendiri. Nilai-nilai mengenai pentingnya kemandirian finansial bagi perempuan ini juga diperoleh dari bagaimana interaksi antara ayah dan ibunya berkenaan dengan uang ini.

Hal tersebut di atas, bersesuaian dengan temuan Domenico dan Jones (2006) yang menyebutkan bahwa faktor pekerjaan orang tua dan harapan orang tua menjadi faktor yang kuat berpengaruh pada aspirasi karir perempuan. Bona, Kelly, dan Jung (2010) juga menyebutkan bahwa faktor pekerjaan orang tua menjadi faktor yang kuat berpengaruh terhadap pilihan karir perempuan. Lebih lanjut Domenico dan Jones (2006) juga menyebutkan tingkat pendidikan menjadi penentu, sebagaimana responden pada studi ini kesemuanya mempunyai tingkat pendidikan tinggi.
Motif berikutnya muncul setelah menikah adalah kebutuhan rasa aman. Hal ini tak lepas dari pengalaman yang dialami setelah responden menikah. Terdapat berbagai variasi pengalaman dari responden. Diantaranya adalah adanya rasa khawatir bahwa pasangannya meninggalkannya, sehingga suatu saat jika misalnya suaminya tidak lagi bersamanya, ia akan tetap dapat mencukupi dirinya sendiri. Pengalaman yang lain adalah adanya kenyataan bahwa pendapatan suami tidak selamanya dapat memenuhi kebutuhan keluarga, sehingga diperlukan sumber pendapatan lain agar terdapat kepastian bahwa kebutuhan keluarga tetap tercukupi. Dalam konteks yang sedikit berbeda, hal ini sesuai dengan temuan Dubey dan Tiwari (2014) yang menyebutkan bahwa salah satu alasan untuk tetap menekuni pekerjaannya setelah menikah adalah untuk memberikan support kepada suami dan keluarga.

Berkenaan dengan pilihan pekerjaan, dari ke enam responden mempertimbangkan faktor peran perempuan ketika sudah menikah, yaitu sebagai ibu rumah tangga. Peran ibu rumah tangga tersebut adalah tanggungjawab penyelenggara utama rumah tangga dan pegasuhan anak-anak. Hal ini sebagaimana temuan Arnold (1993) yang menyebutkan bahkan pada perempuan-perempuan dengan capaian akademik yang tinggi, dalam merencanakan dan menjalankan karirnya, mempertimbangkan peran tradisional perempuan. Hal ini tak lepas pengaruh budaya yang melingkupi, seperti pada temuan (Guy, 2016). Pada risetnya di kalangan Israel-Kristen dan Israel-Muslim, menemukan bahwa sebagai orang dewasa, peran sebagai orang tua merupakan prioritas utama. Sebagaimana temuan pada kalangan akademisi, Dubey dan Tiwari (2014) menyebutkan bahwa pekerjaan rumah tangga dan pengasuhan, merupakan tantangan besar yang dihadapi dalam menjalankan peran ganda ini. 


\section{Pengelolaan Keuangan dalam Keluarga}

Dalam hal pengelolaan keuangan, terdapat tiga macam pengaturan berdasarkan sumber pendaan utama untuk keperluan keluarga. Ketiga macam pengaturan tersebut adalah (1) pembagian pos-pos pengeluaran antara suami dan istri, di mana suami membiayai pos-pos yang dianggap sebagai kebutuhan pokok keluarga, (2) pendapatan suami menjadi sumber pendanaan keperluan keluarga meskipun istri memiliki penghasilan, dan (3) pendapatan istri menjadi sumber pendanaan utama untuk keperluan keluarga. Dari ketiga macam bentuk pendanaan tersebut, semua responden meyakini bahwa kewajiban memenuhi kebutuhan rumah tangga adalah tanggungjawab suami. Hal ini menunjukkan bahwa nilai-nilai tradisional berkenaan dengan pembagian peran di dalam rumah tangga masih dipegang oleh responden, meskipun mereka ini berstatus bekerja dan berpendidikan tinggi. Hal ini menunjukkan bahwa meskipun peran perempuan semakin bertambah, tetap ada upaya untuk melestarikan nilai-nilai tradisional di kalangan perempuan itu sendiri. Upaya tersebut diantaranya dengan tetap selalu menjadikan suami sebagai pengambil keputusan utama, mendorong suami untuk tetap dapat memenuhi kebutuhan keluarga.

Hal ini sejalan dengan temuantemuan sebelumnya, di mana peningkatan peran perempuan dalam hal finansial, tidak serta merta diikuti dengan power sharing yang lebih seimbang antara suami dan istri. Tichenor (1999) menyebutkan bahwa penghasilan yang lebih baik atau pekerjaan yang lebih baik pada perempuan tidak diikuti dengan relasi power yang lebih seimbang pada perkawinan dual earner. Hal yang terjadi pada responden. Temuan Tichenor menunjukkan bahwa pada keluarga dual earner, dengan kesetimbangan baru dalam pembagian peran terutama dalam hal finansial, tidak berpengaruh terhadap nilai-nilai tradisional yang menempatkan suami sebagai pencari nafkah utama di dalam keluarga.

Temuan di atas tentu agak sedikit berbeda dengan hal yang dikemukakan oleh Boehnke (2011). Temuan Boehnke menyebutkan pada perempuan menikah yang bekerja, berpendidikan tinggi mengembangkan sikap egalitarian di dalam rumah tangga. Sedangkan pada temuan studi ini menunjukkan, responden masih melestarikan nilai-nilai tradisional di mana meletakkan power lebih besar pada lakilaki. Pada beberapa ungkapan responden disebutkan bahwa rujukan didikan orang tua dan agama berperan besar dalam cara mereka berinteraksi dengan pasangan.

\section{Tanggapan Responden terhadap Pengelolaan Keuangan Keluarga}

Tanggapan responden pada tiga pola pengelolaan keuangan keluarga tentunya berbeda. Pada pola pertama, di mana terjadi sharing pengeluaran, perempuan merasa lebih percaya diri dan merasa lebih luasa untuk turut memberikan pendapat dan keputusan di dalam keluarga. Hal ini sejalan dengan temuan Blood dan Wolf (dalam Waismel-manor, Levanon, \& Tolbert, 2016). Blood dan Wolf menemukan bahwa semakin tinggi sumber daya yang dimiliki - dalam hal ini adalah pendapatan - semakin leluasa menegosiasikan keinginannya. Pada temuan ini menunjukkan bahwa ketika perempuan berkontribusi secara signifikan pada pengeluaran keluarga, dapat meningkatkan rasa percaya diri dan memiliki posisi tawar yang lebih tinggi untuk kepentingan atau pun pendapatnya. Posisi tawar yang dapat memicu ketidakpuasan ketika pembagian kerja di dalam rumah tangga tidak terdistribusi ulang secara lebih adil setidaknya di mana perempuan, dengan pasangan. Keadaan demikian berdasarkan teori independensi perempuan, dapat meningkatkan resiko terjadinya perceraian. Resiko ini juga dapat muncul dari proses penyesuaian laki-laki yang tidak tepat menghadapi perkembangan penghasilan 
istri, misalnya justru mengembangkan perilaku yang tidak tepat demi untuk menegaskan atau mempertahankan posisi tradisionalnya.

Pada pola kedua adalah pengeluaran keluarga sepenuhnya oleh suami. Dalam hal ini responden melihat bahwa hal tersebut merupakan sebuah kemestian yang secara norma memang menjadi tanggung jawab laki-laki. Ajaran agama merupakan rujukan yang digunakan dalam mengatur pengeluaran keluarga. Pola ketiga menunjukkan bahwa pendapatan istri menjadi sumber utama bagi keluarga. Namun demikian pada penelitian ini, hal ini dianggap sebagai sebuah keadaan sementara. Keadaan ini hanya dipertahankan hingga suami berhasil membangun kembali kekuatan ekonominya melalui pekerjaan atau usaha yang lebih baik. Hal ini menunjukkan bahwa pada responden nilai-nilai tradisional yang menempatkan laki-laki sebagai pencari nafkah utama tetaplah menjadi hal utama.

Pada pola relasi perkawinan yang masih berpegang pada nilai tradisional, namun pada praktiknya pihak perempuan sebagai sumber utama finansial keluarga, pada akhirnya dapat membawa pengaruh negatif pada keluarga. Addo dan Sassler (2010) menemukan bahwa terdapat keterkaitan antara pengaturan keuangan keluarga dengan kepuasan perkawinan, perasaan intimasi, kesesuaian seksual dan kepuasan terhadap resolusi konflik. Penelitian Addo dan Sassler (2010) ini dilakukan pada kelompok sosial ekonomi menengah, belum terbukti pada kelompok sosial yang lebih baik. Meski demikian, jika dilihat temuan keterkaitan antara perubahan pendapatan dengan pembagian kerja di dalam rumah tangga yang membentuk kurva (Tichenor, 1999), temuan ini menemukan relevansinya untuk dievaluasi pada kelompok sosial yang lebih tinggi.

\section{SIMPULAN} bahwa:
1. Motif yang melandasi responden bekerja adalah (1) sudah menjadi citacita sejak sekolah, (2) untuk mendapatkan rasa aman, (3) untuk aktualisasi diri dan (4) sebagai hasil dari sosialisasi terutama dari keluarga.

2. Pilihan pekerjaan lebih didasarkan pada pertimbangan pembagian peran tradisional di mana perempuan memegang peran utama pada domain domestik dan pengasuhan sehingga dipilihlah pekerjaan yang dirasa masih memberi peluang besar untuk tetap dapat menjalankan peran tradisionalnya.

3. Dalam hal pengelolaan keuangan, terdapat tiga macam pola yaitu (1) terjadi pembagian pos-pos pengeluaran antara suami dan istri, di mana suami bertanggungjawab pada pos pengeluaran pokok dimana kriteria pengeluaran pokok ini adalah pengeluaran yang bersifat jangka panjang dan besar, seperti biaya sekolah anak, cicilan rumah, (2) pendapatan suami menjadi sumber pendanaan rumah tangga, istri mengelola dana tersebut untuk keperluan rumah tangga, sedangkan pendapatan istri digunakan untuk keperluan istri, (3) pendapatan istri menjadi sumber pendaan utama di dalam rumah tangga.

4. Tanggapan responden terhadap pengelolaan keuangan yang demikian didasarkan pada pola pengelolaannya adalah (1) merasa adil dan memberi rasa percaya diri pada responden dalam hal turut menentukan visi dan misi keluarga ke depan, (2) responden merasa bahwa memang sudah seharusnyalah demikian, karena dari sisi agama pun diajarkan suami lah yang bertanggungjawab pada keluarga, (3) pola di mana pendapatan istri sebagai sumber utama, responden merasa wajar saja karena suami tengah merintis usaha, dan menganggap keadaan ini sebagai keadaan sementara.

5. Dari pola dan tanggapan responden terhadap pengelolaan keuangan keluarga terdapat satu benang merah 
yaitu adanya keyakinan bahwa lakilaki/suami adalah penanggunjawab utama keluarga, sedangkan istri lebih sebagai pelengkap atau cadangan dalam hal nafkah ini. Artinya pada responden penelitian ini, pola tradisional dalam relasi keluarga masih dipertahankan.

\section{SARAN}

Adapun saran yang dapat diajukan dari temuan studi ini adalah:

1. Narasumber penelitian kecil ini adalah perempuan semata, lebih bagus jika dilakukan triangulasi dengan menggali informasi dari orang-orang di sekitar responden. Misalnya suami, asisten rumah tangga dan rekan kerja atau orang-orang signifikan responden.

2. Perlu dilakukan eksplorasi lebih lanjut pada profesi-profesi lain, sehingga mendapatkan gambaran pola pengelolaan keuangan dan juga motif bekerja yang lebih dapat digeneralisasikan pada populasi perempuan menikah dan bekerja.

3. Perlu dilakukan eksplorasi lebih lanjut mengenai bagaimana efek dari keterlibatan perempuan dalam hal pendanaan keluarga ini, mengingat banyak sekali perceraian terjadi dengan alasan tanggungjawab laki-laki dinilai kurang, padahal jika dilihat dari pemenuhan kebutuhan sehari-hari tak ada yang kurang.

\section{DAFTAR PUSTAKA}

Addo, F. R., \& Sassler, S. (2010). Financial arrangements and relationship quality in low-income couples. Family Relations, 59, 408-423. doi https://doi.org/10.1111/j.17413729.2010.00612.x.

Arnold, K. D. (1993). Undergraduate aspirations and career outcomes of academically talented women: A discriminant analysis. Roeper Review, 15(3), 169-175. doi https://doi.org/10.1080/027831993095 53495.
Bianchi, S. M., Milkie, M. A., Sayer, L. C., \& Robinson, J. P. (2000). Is anyone doing the housework? Trends in the gender division of household labor. Social Forces, 79(1), 191-228.

Boehnke, M. (2011). Gender role attitudes around the globe: Egalitarian vs. traditional views. Asian Journal of Social Science, 39(1), 57-74. doi https://doi.org/10.1163/156853111X55 4438.

Bona, L., Kelly, A., \& Jung, M. (2010). Exploring factors contributing to women's nontraditional career aspirations. Psi Chi Journal of Undergraduate Research, 15(3), 123130.

Braun, V., \& Clarke, V. (2006). Using thematic analysis in psychology. Qualitative Research in Pschology, 3(2), 77-101.

Brown, H., \& Roberts, J. (2014). Gender role identity, breadwinner status and psychological well-being in the household. Sheffield Economic Research Paper Series. The University of Sheffield., (2014004), 1-33.

Craig, L. (2007). Is there really a second shift, and if so, who does it? A timediary investigation. Feminist Review, 86, 149-170.

Dema-Moreno, S. (2009). Behind the negotiations: Financial decisionmaking processes in Spanish dual income couples. Feminist Economics, 15(1), 27-56. doi https://doi.org/10.1080/135457008026 20575.

Domenico, D. M., \& Jones, K. H. (2006). Career aspirations of women in the 20th century. Journal of Career and Technical Education, 22(2), 1-7.

Dubey, N., \& Tiwari, V. (2014). Factors affecting career aspirations among married women. Indian Journal of Health and Wellbeing, 5(7), 59-63.

Fontana, A., \& Frey, J. H. (2009). Wawancara seri ilmu pengetahuan. In N. K. Denzin \& Y. S. LIncoln (Eds.), 
Handbook of qualitative research (Terjemah) (Kedua). Yogyakarta: Pustaka Pelajar.

Guy, A. (2016). The impact of cultural orientation and higher education on young Israeli Jewish and Arab adults' notion of the adaptive adult. Children \& Society, 30, 204-219. doi https://doi.org/10.1111/chso.12124.

Kan, M. Y., \& He, G. (2018). Resource bargaining and gender display in housework and care work in Modern China. Chinese Sociological Review, 50(2), 188-230. doi https://doi.org/10.1080/21620555.2018 $.1430506 \mathrm{f}$

Karasu, S. R. (2007). The instituion of Marrige: Terminable or interminable. American Journal of Psychotherapy, 61, 1-16.

Kulik, L. (1999). Marital power relations, resources and gender role ideology: A multivariate model for assessing effects. Journal of Comparative Family Studies, 30(2), 189-206.

Lennon, M. C., \& Rosenfield, S. (1994). Relative fairness and the division of housework: The importance of options. American Journal of Sociology, 100(2), 506-531.

Mannino, C. A., \& Deutsch, F. M. (2007). Changing the division of household labor: A negotiated process between partners. Sex Roles, 56, 309-324. doi https://doi.org/10.1007/s11199-0069181-1.

Smit, R. (2002). The changing role of the husband father in dual earner family in South Africa. Journal of Comparative Family Studies, 33(3), 401-415.

Statistik, B. P. (2018). Keadaaan ketenagakerjaan Indonesia Februari 2018. Jakarta.

Tichenor, V. J. (1999). Status and income as gendered resources: The case of marital power. Journal of Marriage and Family, 61(3), 638-650.

Treas, J., \& Tai, T. (2012). How couples manage the household: Work and power in cross-national perspective. Journal of Family Issues, 33(8), 10881116. doi https://doi.org/10.1177/0192513X1142 6700 .

Waismel-manor, R., Levanon, A., \& Tolbert, P. S. (2016). The impact of family economic structure on dualearners' career and family satisfaction. Sex Roles, 75, 349-362. doi https://doi.org/10.1007/s11199-0160620-3.

Wilkie, J. R., Ferre, M. M., \& Ratcliff, K. S. (1998). Gender and fairness: Marital satisfaction in two-earner couples. Journal of Marriage and Familly, 60(3), 577-594. 